ISSN 0206-5657. Вісник Львівського університету. Серія біологічна. 2017 Випуск 75. С. 48-53 Visnyk of the Lviv University. Series Biology. 2017. Issue 75. P. 48-53

УДК $581.1+582.54$

\title{
ISOENZYME DIVERSITY WITHIN GENUS MELICA (POACEAE) - SYSTEMATIC IMPLICATIONS
}

\author{
G. Angelov ${ }^{1}$, I. Bednarska ${ }^{2}$ \\ ${ }^{1}$ Institute of Biodiversity and Ecosystem Research, Bulgarian Academy of Sciences \\ 23, Acad. G. Bonchev St., bl. 1113, Sofia, Bulgaria \\ e-mail: jorkata_1953@mail.bg \\ ${ }^{2}$ Institute of Ecology of the Carpathians, NAS of Ukraine \\ 4, Kozelnytska St., Lviv 79026, Ukraine \\ e-mail:ibednarska@ukr.net
}

\begin{abstract}
Polyacrylamide gel electrophoresis (PAGE) of six enzymes was employed to reveal the systematic position and relationships of four species within genus Melica. The variation of the isoenzymes anodal esterase, cathodal peroxidase, acid phosphatase, superoxide dismutase, amylase and glutamate dehydrogenase was analyzed. The aim of the present study was to examine the variation of a set of isoenzymes in attempt to evaluate the systematic position and relationships of four species of genus Melica L. Systematic relationships were evaluated by calculating coefficient of divergence D. The species M. uniflora was clearly differentiated from M. ciliata and M. transsilvanica. Moreover, the species M. uniflora possessed two species-specific isoforms. It was shown that the species M. nutans is closely related to M. uniflora but genetically is a well defined entity within genus Melica. The results of the present study correlated well with the main morphological features of the examined taxa of genus Melica.
\end{abstract}

Keywords: Melica, PAGE, isoenzymes, variation, systematic relationships

The species Melica nutans L. is shortly-rhizomatous, long-lived perennial grass. Spikelets are 6-8 $\mathrm{mm}$ long, eventually nodding, with $2-3$ fertile florets, falling together when ripe. Diploid, $2 \mathrm{n}=18$. While several European Melica species are very variable and subjected to different taxonomic treatments, Melica nutans is morphologically homogenous [1]. This species occupies shady and often rocky places. It is distributed mostly of Europe, but rarely in Mediterranean region and the islands [14].

Species M. uniflora Retz. is rhizomatous, perennial grass. Spikelets are $3-7 \mathrm{~mm}$ long, erect, with 1 fertile floret, diploid, $2 \mathrm{n}=18$. It occurs mainly in shady places. Its range of distribution in Europe is northwards to Scotland, and eastwards to Moldova [14] and the neighboring south-western regions of Ukraine [5].

The complex Melica ciliata - M. transsilvanica consists of group of sub-Mediterraneancontinental species. Intricate morphological variability and traits overlapping makes the Melica ciliata - M. transsilvanica complex a taxonomically problematic group [4]. The morphological variability concerns mainly indumentum of plants' vegetative parts and type of panicle branching. For the existence of continual variability, the number of taxa and its rank differ significantly in the taxonomic conception of different authors $[11,14,18]$. This circumstance causes confusion in synonymy as well disagreement concerning the distribution of some taxa. In particular, question about the eastern border of Melica ciliata s.str. is still disputable. According to Szczepaniak \& Cieślak [13], M. ciliata is sub-Mediterranean species whose main continuous geographical range covers the area from the Atlantic and Mediterranean region, Central Europe, to southern

(C) Ангелов Г., Беднарська I., 2017 
Ukraine and the Crimea. However, Ukrainian authors found that M. ciliata s.str. is very rare species in Podolian upland's south regions [5] and Transcarpathia.

The analysis of morphological characters proved to be insufficient for the proper taxa distinction within the complex Melica ciliata-M. transsilvanica. So, alternative diagnostic molecular markers were used. Study of genetic and morphological variation in natural populations of Melica ciliata and M. transsilvanica by DNA markers $[12,13]$ demonstrated effectiveness of AFLP analysis. Moreover, it was shown that earlier reported localities in Poland are wrong and this species does not occur in Poland. Despite of effectiveness of AFLP method for large-scale studies within Europe, it is expensive and rather laborious for smaller regional studies. Alternatively, the isoenzyme analysis is also widely employed in biosystematic studies. Large-scale geographic patterns in widespread Euroasian woodland grass $M$. nutans were studied by sets of isoenzyme systems $[15,16,17]$. Electrophoretic patterns of six isoenzymes in Bulgarian populations of M. uniflora were examined in order to reveal their isoenzyme variation [1].

The aim of the present study was to examine the variation of a set of isoenzymes in attempt to evaluate the systematic position and relationships of the above listed species. Within genus Melica L. The analysis of populations from the main parts of species' distribution, e.g. Bulgaria, will result in adequate comparative data.

\section{Material and methods}

The enzymes anodal esterase (EST), cathodal peroxidase (PER), acid phosphatase (ACP), superoxide dismutase (SOD), amylase (AMY) and glutamate dehydrogenase (GDH) were analyzed individually in two natural populations of each Melica transsilvanica, M. ciliata, M. uniflora, and M. nutans from Bulgaria. Leaves were grinded in $0.01 \mathrm{M}$ Tris, $0.08 \mathrm{M}$ glycine, 0.005 $\mathrm{M}$ cysteine, $20 \%$ sucrose, $\mathrm{pH}$ 8.3. Anodally migrating isoforms were resolved on $7.5 \%$ polyacrilamide slab gels as described [3]. The cathodal PER was run on $7.5 \%$ polyacrylamide slab gels [7]. The length of gels was $10 \mathrm{~cm}$ for AMY, $7.5 \mathrm{~cm}$ for ACP and GDH, $7 \mathrm{~cm}$ for SOD, $6.25 \mathrm{~cm}$ for anodal EST and $6 \mathrm{~cm}$ for cathodal PER. The following staining recipes were used: AMY [7], PER [6], EST [8], GDH and ACP [9], SOD [2].

Systematic relationships among the above mentioned taxa of genus Melica were assessed by calculating coefficient of divergence D (15) according to the following formula:

$$
D=\sqrt{\frac{1}{N} \sum_{i=1}^{N}\left(x_{i j}-x_{k}\right)^{2}}
$$

where, $\mathrm{N}$ is the number of isoforms for each enzyme, $\mathrm{x}_{\mathrm{ij}}$ and $\mathrm{x}_{\mathrm{ik}}$ are the mean frequencies of $\mathrm{i}$-th isoform in taxa $\mathrm{j}$ and $\mathrm{k}$.

\section{Results and discussion}

Anodal esterase. Totally eight isoforms of the enzyme were electrophoretically resolved in Melica transsilvanica, M. ciliata, M. uniflora and M. nutans (Table 1). Isoform 43 was shared by all species, being rare (frequency of 0.04) in M. ciliata. Excepting Melica transsilvanica, isoforms 16 and 32 were common for the rest of taxa. Similarly, isoform 19 was observed in all taxa but M. uniflora. The values of coefficient D indicated that the species M. uniflora and M. nutans were most closely related $(\mathrm{D}=0.11)$ while the former was most distantly positioned $(\mathrm{D}=0.25)$ from Melica transsilvanica.

Cathodal peroxidase. Nine isoforms of the enzyme were found in the populations of the studied species group (Table 2). Most of isoforms were shared by all species. Excepting Melica transsilvanica, isoform 28 was monomorphically fixed throughout the studied group. Isoform 34 was invariant in M. uniflora and M. nutans. Isoform 55 was species-specific for the species 
M. uniflora. The values of coefficient D varied in a narrow range (0.14-0.18) and the studied taxa proved to be almost equidistantly positioned as judged by molecular marker cathodal peroxidase.

Table 1

Mean isoform frequencies of anodal esterase in the studied populations of Melica uniflora, M. nutans, M. ciliata and M. transsilvanica

\begin{tabular}{|l|c|c|c|c|c|c|c|c|}
\hline \multicolumn{1}{|c}{ Species } & \multicolumn{7}{c|}{ Isoforms } & \multicolumn{1}{c|}{$c \mid$} \\
\cline { 2 - 8 } & 9 & 11 & 16 & 19 & 24 & 31 & 32 & 43 \\
\hline M. uniflora & 0.00 & 0.79 & 0.74 & 0.00 & 0.00 & 0.09 & 0.23 & 0.31 \\
M. nutans & 0.12 & 0.48 & 0.64 & 0.12 & 0.42 & 0.22 & 0.65 & 0.84 \\
M. ciliata & 0.03 & 0.00 & 0.96 & 0.96 & 0.00 & 0.00 & 0.16 & 0.04 \\
M. transsilvanica & 0.00 & 0.00 & 0.00 & 0.12 & 0.75 & 0.12 & 0.00 & 0.12 \\
\hline
\end{tabular}

Table 2

Mean isoform frequencies of cathodal peroxidase in the studied populations of Melica uniflora, M. nutans, M. ciliata and M. transsilvanica

\begin{tabular}{|c|c|c|c|c|c|c|c|c|c|}
\hline \multirow{2}{*}{ Species } & \multicolumn{9}{|c|}{ Isoforms } \\
\hline & 20 & 25 & 28 & 30 & 32 & 34 & 38 & 50 & 55 \\
\hline M. uniflora & 0.58 & 1.00 & 1.00 & 1.00 & 0.00 & 1.00 & 0.42 & 0.39 & 0.13 \\
\hline M. nutans & 0.14 & 0.82 & 1.00 & 0.14 & 0.72 & 1.00 & 0.92 & 0.78 & 0.00 \\
\hline M. ciliata & 0.75 & 1.00 & 1.00 & 0.25 & 0.79 & 0.71 & 0.17 & 0.00 & 0.00 \\
\hline M. transsilvanica & 0.62 & 0.88 & 0.62 & 0.62 & 0.00 & 0.75 & 0.50 & 0.00 & 0.00 \\
\hline
\end{tabular}

Acid phosphatase. In total, nine isoforms of ACP were detected in the studied species of genus Melica (Table 3). Most of isoforms, namely 11, 14, 26, 30, 34, were shared by all examined species. Similarly, isoform 29 occurred in all studied taxa but $M$. uniflora. The values of coefficient D ranged from 0.09 ( $M$. nutans vs $M$. transsilvanica) to 0.14 for the species pairs $M$. transsilvanica/ M. uniflora and M. ciliata/ M. nutans, respectively.

Table 3

Mean isoform frequencies of acid phosphatase in the studied populations of Melica uniflora, M. nutans, M. ciliata and M. transsilvanica

\begin{tabular}{|l|c|c|c|c|c|c|c|c|}
\hline \multicolumn{1}{|c}{ Species } & \multicolumn{10}{c|}{ Isoforms } & \multicolumn{1}{c|}{} \\
\cline { 2 - 9 } & 11 & 14 & 18 & 22 & 26 & 29 & 30 & 34 \\
\hline M. uniflora & 0.32 & 0.32 & 0.22 & 0.46 & 1.00 & 0.00 & 0.59 & 0.59 \\
M. nutans & 0.52 & 0.64 & 0.00 & 0.00 & 0.64 & 0.08 & 0.32 & 0.32 \\
M. ciliata & 0.04 & 0.79 & 0.00 & 0.63 & 0.46 & 0.21 & 0.79 & 0.12 \\
M. transsilvanica & 0.63 & 0.89 & 0.12 & 0.00 & 0.50 & 0.25 & 0.77 & 0.12 \\
\hline
\end{tabular}

Superoxide dismutase. Nine isoforms of the enzyme marker SOD were detected in the studied species of genus Melica (Table 4). Monomorphically-fixed isoform 60 was common for the whole species group. Isoforms 30, 40, 44 and 48 were also detected with different frequencies in all examined taxa. Isoform 57 was species-specific for $M$. uniflora. The values of coefficient D fluctuated from 0.06 (M. nutans vs M. transsilvanica) to 0.18 when $M$. ciliata and M. transsilvanica were contrasted.

Table 4

Mean isoform frequencies of superoxide dismutase in the studied populations of Melica uniflora, M. nutans, M. ciliata and M. transsilvanica

\begin{tabular}{|l|c|c|c|c|c|c|c|c|c|}
\hline \multirow{2}{*}{\multicolumn{1}{c|}{ Species }} & \multicolumn{10}{c|}{ Isoforms } \\
\cline { 2 - 9 } & 25 & 30 & 40 & 44 & 48 & 50 & 54 & 57 & 60 \\
\hline M. uniflora & 0.58 & 0.42 & 0.58 & 0.23 & 0.13 & 0.97 & 0.39 & 0.33 & 1.00 \\
M. nutans & 0.23 & 0.16 & 0.32 & 0.00 & 0.54 & 0.45 & 0.18 & 0.00 & 1.00 \\
M. ciliata & 0.00 & 0.78 & 1.00 & 0.21 & 0.04 & 0.00 & 0.00 & 0.00 & 1.00 \\
M. transsilvanica & 0.00 & 0.12 & 0.75 & 0.12 & 0.75 & 0.75 & 0.00 & 0.00 & 1.00 \\
\hline
\end{tabular}


Amylase. Totally eight isoforms of the enzyme were electrophoretically resolved in Melica transsilvanica, M. ciliata, M. uniflora and M. nutans (Table 5). Isoform 10 was shared by all studied species. Excepting M. uniflora, isoform5 was also common for the whole group. Isoforms 40 and 44 were observed in $M$. uniflora and M. nutans only. In similar, isoform 8 was specific for species pair Melica transsilvanica, M. ciliata. The values of coefficient D varied in a wide range - from 0.11 (M. uniflora and M. nutans) to 0.30 when M. ciliata and M. transsilvanica were compared.

Table 5

Mean isoform frequencies of amylase in the studied populations of Melica uniflora, M. nutans, M. ciliata and M. transsilvanica

\begin{tabular}{|l|c|c|c|c|c|c|c|c|}
\hline \multicolumn{1}{|c}{ Species } & \multicolumn{10}{c|}{ Isoforms } \\
\cline { 2 - 9 } \multicolumn{1}{|c}{ M. uniflora } & 5 & 8 & 10 & 17 & 20 & 26 & 40 & 44 \\
\hline M. nutans & 0.00 & 0.00 & 0.22 & 1.00 & 0.00 & 0.00 & 0.88 & 0.44 \\
M. ciliata & 0.42 & 0.00 & 0.48 & 1.00 & 0.34 & 0.16 & 0.48 & 0.24 \\
M. transsilvanica & 0.79 & 0.26 & 0.53 & 0.00 & 1.00 & 1.00 & 0.00 & 0.00 \\
\hline
\end{tabular}

Glutamate dehydrogenase. In total, five isoforms of the enzyme were detected in the studied species of genus Melica. Isoforms 13 and 15 were common for the whole studied group. The species $M$. nutans shared the electrophoretic patterns of $M$. uniflora. Thus, the latter two taxa possessed identical isoenzyme structure in respect to the enzyme marker glutamate dehydrogenase.

The mean values of coefficient D averaged over the five enzymes surveyed, namely anodal EST, catodal PER, ACP, SOD and AMY, are shown in Table 6 and graphically in Figure.

Table 6

Mean values of coefficient D for pair-wise comparisons among the studied taxa of genus Melica

\begin{tabular}{|c|c|c|c|c|c|}
\hline \multirow{2}{*}{ Species } & \multicolumn{5}{|c|}{ Mean values of coefficient D } \\
\hline & Number & 1 & 2 & 3 & 4 \\
\hline M. uniflora & 1 & 0.00 & & & \\
\hline M. nutans & 2 & 0.12 & 0.00 & & \\
\hline M. ciliata & 3 & 0.17 & 0.17 & 0.00 & \\
\hline M. transsilvanica & 4 & 0.17 & 0.13 & 0.19 & 0.00 \\
\hline
\end{tabular}

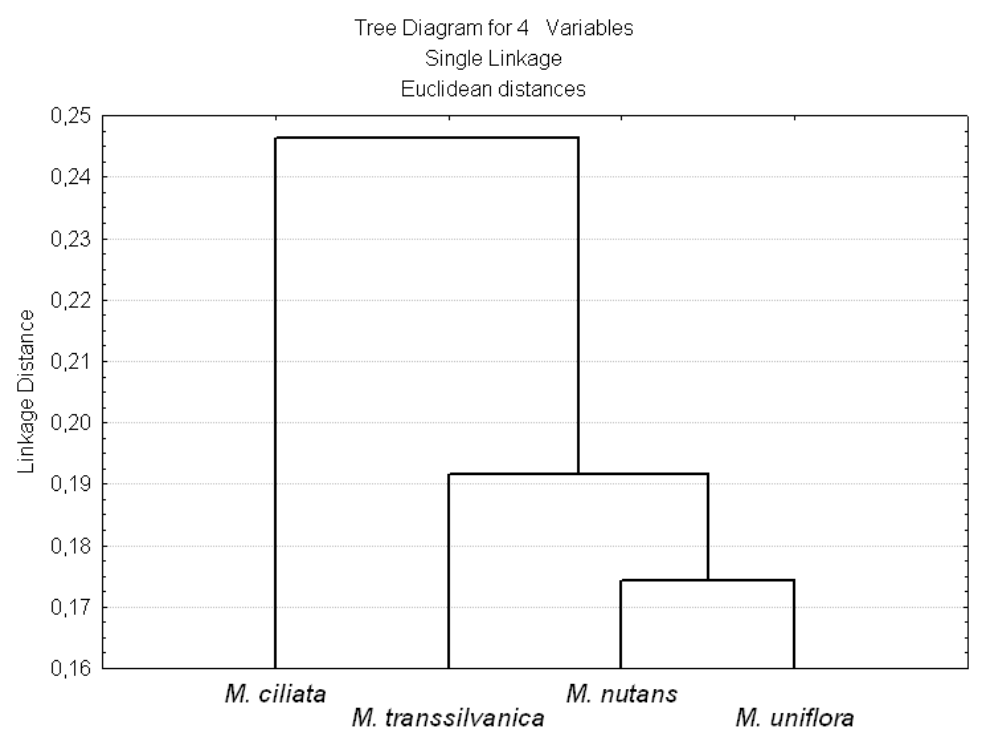

The dendrogram of Cluster analysis for four Melica species on the base D coefficient 
Pair-wise comparisons of M. uniflora with species M. ciliata and M. transsilvanica resulted in high values of coefficient $\mathrm{D}$ equal to 0.17 in both cases. Thus, it was clearly differentiated from species pair $M$. ciliata and $M$. transsilvanica. It should be noted that the mean value of coefficient D for the comparison between $M$. nutans and M. uniflora was the lowest one (0.12) - an indication for high similarity of isoenzyme structure of both taxa. In addition, the species M. uniflora possessed two species-specific isoforms. This result demonstrated that the species M. nutans and M. uniflora are closely related taxa within genus Melica. It should be pointed out that both $M$. nutans and $M$. uniflora are rhizomatous plants while the species M. ciliata and $M$. transsilvanica are caespitose ones. Moreover, M. nutans and M. uniflora are among the minority of species within the genus which are characterized with obtuse and glabrous lemma, while the rest of species have pointed (acute) lemma with long hairs. Thus, they were clearly differentiated from both $M$. ciliata and $M$. transsilvanica. Thus, the results of the present study correlated with the main morphological features of the examined taxa of genus Melica.

\section{REFERENCES}

1. Angelov $G$. Electrophoretic spectra of six isoenzymes in natural populations of Melica uniflora (Poaceae) from Bulgaria // Compt. Rend. Acad. Bulg. Sci. 2012. Vol. 65(8). P. 1071-1077.

2. Baur E., Schorr R. Genetic polymorphism of tetrazolium oxidase in dogs // Sci. 1969. Vol. 166. P. 1524-1525.

3. Davis B. Disc electrophoresis. I. Method and application to human serum proteins // Ann. N.Y. Acad. Sci. 1964. Vol. 121. P. 404-427.

4. Hempel $W$. Taxonomische und chorologische Untersuchungen an Arten von Melica L. subgen. Melica L. // Feddes Repert. 1970. Vol. 81. P. 131-145.

5. Prokudin Yu. N., Vovk A. G., Petrova O. A., Ermolenko E. D. et Verniczenko Yu. V. (eds.). Zlaki Ukrainy (Grasses of Ukraine). Kyiv: Naukova Dumka, 1977. P. 389-399.

6. Przybylska J., Blixt S., Parzysz H., Zimniak-Przybylska Z. Isoenzyme variation in the genus Pisum. I. Electrophoretic patterns of several enzyme systems // Genet. Polon. 1982. Vol. 23. P. 103-121.

7. Reisfeld R., Lewis U., Williams D. Disc electrophoresis of basic proteins and peptides on polyacrylamide gels // Nature. 1962. Vol. 195. P. 281-283.

8. Schmidt-Stohn G., Wehling P. Genetic control of esterase isoenzymes in rye (Secale cereale L.) // Theor. Appl. Genet. 1983. Vol. 64. P. 109-115.

9. Shaw C., Prasad R. Starch gel electrophoresis - a compilation of recipes // Biochem. J. 1970. Vol. 4. P. 297-320.

10. Stuessy T. Plant Taxonomy. New York: Columbia Univ. Press. 1990.

11. Szczepaniak M. Struktura filogeograficzna gatunków kompleksu Melica ciliata - M. transsilvanica (Poaceae) w Europie // Fragmenta Floristica et Geobotanica Polonica. 2013. Vol. 20 (1). P. 109-130.

12. Szczepaniak M., Cieślak E. Genetic variation and structure in natural populations of Melica ciliata and M. transsilvanica (Poaceae) as indicated by AFLP markers // Biodiv. Res. Conserv. 2006. Vol. 3-4. P. 39-43.

13. Szczepaniak M., Cieślak E. Genetic and morphological differentiation between Melica ciliata L. and M. transsilvanica Schur (Poaceae) in Europe reveals the non-existence of M. ciliata in the Polish flora // Acta Soc. Bot. Pol. 2011. Vol. 80(4). P. 301-313.

14. Tutin T. Melica L. - In: Tutin, T.G. et al. (eds.). Flora Europaea. Cambridge Univ. Press, Cambridge. 1980. Vol. 5. P. 178-179. 
15. Tyler T. Geographic variation and dispersal history in Fennoscandian populations of two forest herbs // Plant. Syst. Evol. 2002a. Vol. 233. P. 47-64.

16. Tyler T. Large-scale geographic patterns of genetic variation in Melica nutans a widespread Eurasian woodland grass // Plant. Syst. Evol. 2002b. Vol. 236. P. 73-87.

17. Tyler T. Studies in the Melica ciliata complex: Distribution of allozyme variation within and among individuals, populations and geographic regions // Plant Syst. Evol. 2004. Vol. 248. P. 1-30.

Стаття: надійшла до редакиії 03.02.17

прийнята до друку 16.03 .17

\title{
РIЗНОМАНІТНІСТЬ IЗОЕНЗИМІВ У МЕЖАХ РОДУ МЕLICA (РОАСЕАЕ) - РЕЗУЛЬТАТИ ВИКОРИСТАННЯ В СИСТЕМАТИЦІ
}

\author{
Г. Ангелов ${ }^{1}$, І. Беднарська ${ }^{2}$ \\ ${ }^{1}$ Інститут Біорізноманіття та Вивчення Екосистем \\ Болгарської академії наук \\ вул. акад. Г. Бончева, 23, Софія 1113, Болгарія \\ e-mail: jorkata1953@mail.bg \\ ${ }^{2}$ Інститут екології Карпат НАН Украӥни \\ вул. Козельницька, 4, Львів 79026, Україна \\ e-mail: ibednarska@ukr.net
}

3 метою оцінки систематичного положення та взаємовідносин між чотирма видами роду Melica було використано електрофорез шести ферментів у поліакриламідному гелі (PAGE). Проведено аналіз мінливості ізоферментів анодної естерази, катодної пероксидази, кислої фосфатази, супероксиддисмутази, амілази і глутаматдегідрогенази. Систематичні відносини оцінювали шляхом розрахунку коефіцієнта дивергенції. Встановлено, що за набором зазначених молекулярних маркерів Melica uniflora чітко відрізняється від M. ciliata та M. transsilvanica. Крім того, M. uniflora містить дві видоспецифічні ізоформи. Також було показано, що M. nutans тісно пов'язана з M. uniflora, проте генетично вид досить добре вирізняється в межах роду Melica. Представлені результати виявилися добре скорельовані 3 діагностично значущими ознаками морфологічної будови досліджених таксонів роду Melica.

Ключові слова: Melica, PAGE, ізоензими, мінливість, систематичні взаємовідносини 